\title{
Effect of mulching practices on growth and yield of forage crops under rainfed ecosystem
}

\author{
Himangshu Das ${ }^{1 *}$, Champak Kumar Kundu², Prasanta Kumar Bandyopadhyay ${ }^{3}$, Sahuji \\ Bandyopadhyay $^{2}$ and Pintoo Bandopadhyay ${ }^{2}$
}

${ }^{1}$ AMFU Malkangiri, Orissa University of Agriculture and Technology, KVK Malkangiri, Mundaguda, Malkangiri, Odisha- 764045, INDIA

${ }^{2}$ Department of Agronomy, Bidhan Chandra Krishi Viswavidyalaya, Mohanpur, Nadia, West Bengal- 741252 , INDIA

${ }^{3}$ Department of Agril. Chemistry and Soil Science, Bidhan Chandra Krishi Viswavidyalaya, Mohanpur, Nadia, West Bengal- 741252, INDIA

*Corresponding author. E-mail: hdubkv@gmail.com

Received: September 16, 2017; Revised received: October 16, 2017; Accepted: February 2, 2018

\begin{abstract}
There had been very less systemic study of forage crops in this part of the world. The information is scanty and not well documented. With these backgrounds, a field experiment was conducted during winter and summer season of 2012-13 and 2013-14 with three forage crops [Brachiaria brizantha, Panicum maximum and Setaria anceps] and three mulching managements [no mulching, soil dust mulching and live mulching]. Experiment was laid out in split plot design with three replications. Forage crop was assigned to the main plots and mulching to the subplots. The results revealed that superior growth attributes as well as highest green fodder yield $\left(91.14 \mathrm{q} \mathrm{ha}^{-1}\right.$ in winter and $307.20 \mathrm{q} \mathrm{ha}^{-1}$ in summer) and dry matter yield (26.27 q ha-1 in winter and $66.99 \mathrm{q} \mathrm{ha}^{-1}$ in summer) were obtained with forage crop Setaria anceps. Mulching influenced all growth parameters (plant height, leaf area index and crop growth rate) significantly and recorded highest with live mulching followed by soil dust and no mulching. Adoption of live mulching resulted in highest green fodder yield (94.17 q ha-1 in winter and $309.58 \mathrm{q} \mathrm{ha}^{-1}$ in summer) as well as highest dry matter yield (26.28 q ha-1 in winter and $71.93 \mathrm{q} \mathrm{ha}^{-1}$ in summer). The present experimental findings signify the importance of live mulching in improving growth attributes and yield of forage crops.
\end{abstract}

Keyword: Forage crop, Growth, Mulching, Yield

\section{INTRODUCTION}

Livestock industry demonstrate a beneficial impact on rural people in India by improving their income, employment and consumption thereby acting as a potential tool in lightening the rural poverty. The Livestock sector plays a key role in providing livelihoods to seventy million rural households (DADF, Annual Report, 2016-17, Govt. of India). The major challenge facing the livestock sector is to fulfil the needs of feed for the increasing population. The total area under cultivated fodder in India is only $8.6 \mathrm{~m}$ ha (Kaur and Goyal, 2017). The scarcity of feed is a serious problem in India for proper growth and production of livestock sector. Hence, livestock improvement through the nutritional development is of paramount importance. Forages are the main diet of animal and their production is the backbone of livestock industry. Adequate availability of feed and fodder to livestock is vital for increasing the productivity. At present, the country faces a net deficit of $36 \%$ greens, $40 \%$ dry fodder and $57 \%$ concentrates (DADF, Annual Report, 2014-15, Govt. of
India). This gap between demand and supply may further rise due to consistent growth of livestock population at the rate of $1.23 \%$ in the coming years (Kumar et $a l ., 2012$ ). While improving the forage production, it is necessary to address the opportunities related to production and efficient use of resources. Among the different resource conservation measures, mulching has gained popularity. It is used for various reasons but water conservation due to reduction in evaporation loss of soil water (Teame et al., 2017; Kumar and Lal, 2012) and erosion control (Patil et al., 2013) are the most important objective for its use in agriculture. Other reason for mulching use includes soil temperature modification (Kumar et al., 2014), increasing the soil organic carbon (Bajoriene et al., 2013; Kumar et al., 2014), nutrient addition (Patil et al., 2016), improvement of soil properties (Kumar, 2014) and control weeds (Kumar et al., 2014). Thus, it facilitates more retention of soil moisture and helps in control of temperature fluctuations, improves physical, chemical and biological properties of soil, as it adds nutrients to the 
soil and ultimately enhances the growth and yield of crops. Hence it was felt necessary to study the effect of mulching on growth and yield of perennial forage crops.

\section{MATERIALS AND METHODS}

The present investigation was carried out at central research farm of Bidhan Chandra Krishi Viswavidyalaya, Nadia, West Bengal during the winter and summer season of 2012-13 and 2013-14 on perennial forage crops. The mean minimum and maximum temperatures were 18.31 to $31.25^{\circ} \mathrm{C}$ and 18.55 to $31.19^{\circ} \mathrm{C}$ during $1^{\text {st }}$ and $2^{\text {nd }}$ year of study, respectively. A total of $9.20 \mathrm{~mm}$ rainfall received during winter season of $1^{\text {st }}$ year, but there was no rainfall in winter season of $2^{\text {nd }}$ year. In summer season, total of 327.60 and 209.90 $\mathrm{mm}$ rainfall received during $1^{\text {st }}$ year and $2^{\text {nd }}$ year, respectively (data collected from AICRP on Agrometeorology, BCKV). The experimental soil was sandy loam in texture having $\mathrm{pH} 7.2$ (Jackson, 1967), organic carbon $0.51 \%$ (Walkey and Black, 1934) and available nitrogen (Subbaiah and Asija, 1956), phosphorus (Jackson, 1973) and potassium (Schollenberger and Simon, 1945) as $190.4,12.5$ and $145.6 \mathrm{~kg} \mathrm{ha}^{-1}$, respectively. The experiment was laid out in split plot design with three replications. Three different perennial forage crops (Brachiaria brizantha, Panicum maximum and Setaria anceps) kept in the main plots. The subplots consisted of three mulches (no mulching, soil dust mulching and live mulching). This experiment was started in an experimental field of two years aged perennial grass. During establishment of this experiment a spacing of $50 \mathrm{~cm} \times 50 \mathrm{~cm}$ (plant $\mathrm{x}$ row) was maintained for each treatment. Crop for live mulching was sown by opening of furrow with tyne in between two lines of perennial grass at the same time soil dust mulch was made by loosening of surface layer. In winter seasons berseem @ $20 \mathrm{~kg} \mathrm{ha}^{-1}$ and in summer season cowpea@30 kg ha ${ }^{-1}$ were sown as live mulch. Live mulching was cut after 45 days of sowing and spread over the soil surface in between two lines of perennial grasses. A top dressing of $50 \mathrm{~kg} \mathrm{~N} \mathrm{ha}^{-1}$ was applied at the time of initiation of winter season. In case of summer season $50 \mathrm{~kg} \mathrm{~N} \mathrm{ha}{ }^{-1}$ was applied during initiation of season and another $50 \mathrm{~kg} \mathrm{ha}^{-1}$ after $1^{\text {st }}$ cutting. Once in a year each of potassium (K) and phosphorus $(\mathrm{P})$ were also added to the field during rainy season at the rate of $50 \mathrm{~kg} \mathrm{ha}^{-1}$. The crops were cultivated in rainfed condition.

Observations on growth attributes were counted at 15 days interval. The plant height was measured from the base of the plant to the tip of the upper leaf and expressed in centimeters $(\mathrm{cm})$. Leaf area index (LAI) was obtained by using area-weight relationship where leaf areas of dried leaf samples were worked out (Kemp, 1960). Crop growth rate (CGR) was calculated by using the following formula (Watson, 1947):

CGR $\left(\mathrm{g} \mathrm{m}^{-2}\right.$ day $\left.^{-1}\right)=\mathrm{W}_{2}-\mathrm{W}_{1} / \mathrm{t}_{2}-\mathrm{t}_{1} \quad$------ (I)

Where, $\mathrm{W}_{1}$ and $\mathrm{W}_{2}$ were the plant dry weights $\left(\mathrm{g} \mathrm{m}^{-2}\right)$ at time $t_{1}$ and $t_{2}$, respectively.

The plants from the net plot area were cut at $15 \mathrm{~cm}$ above the ground level at the time of each cut and fresh weight $\left(\mathrm{kg} \mathrm{plot}^{-1}\right)$ was recorded. Based on this green forage yield $\left(\mathrm{q} \mathrm{ha} \mathrm{h}^{-1}\right.$ ) was calculated. From the fresh forage, $500 \mathrm{~g}$ harvested material was placed in the hot air oven at $65-70^{\circ} \mathrm{C}$ to a constant weight and dry weight was recorded. In winter season cutting was made after 90 days of initiation of season (only single cut was possible due slow growth rate) and in summer season it was done at two times one after 45 days after initiation and second one after 45 days of first cutting. Based on the percent dry matter, treatment wise dry matter yield was converted into $\mathrm{q} \mathrm{ha}^{-1}$. Data was statistically analyzed using analysis of variance (ANOVA) as split-plot design (Gomez and Gomez, 1984). Further Significant differences between the treatments were compared with the critical difference at $\pm 5 \%$ probability by least significant difference.

\section{RESULTS AND DISCUSSION}

Growth attributes: Plant height was significantly influenced by different forage crops in all the date of observations in both winter and summer seasons

Table 1. Effect of mulching on plant height $(\mathrm{cm})$ of forage crops during two seasons (pooled data of two years)

\begin{tabular}{lcccccccccccc}
\hline & \multicolumn{1}{c}{ Winter season } & \multicolumn{10}{c}{ Summer season } \\
\cline { 2 - 13 } Treatments & $\mathbf{1 5}$ & $\mathbf{3 0}$ & $\mathbf{4 5}$ & $\mathbf{6 0}$ & $\mathbf{7 5}$ & $\mathbf{9 0}$ & $\mathbf{1 5}$ & $\mathbf{3 0}$ & $\mathbf{4 5}$ & $\mathbf{6 0}$ & $\mathbf{7 5}$ & $\mathbf{9 0}$ \\
& DAI & DAI & DAI & DAI & DAI & DAI & DAI & DAI & DAI & DAI & DAI & DAI \\
\hline Forage crops & & & & & & & & & & & \\
\hline Brachiaria brizantha & 28.00 & 30.47 & 35.27 & 37.91 & 40.36 & 42.31 & 39.29 & 48.72 & 64.97 & 38.65 & 53.46 & 70.03 \\
Panicum maximum & 32.78 & 37.58 & 45.22 & 49.97 & 57.20 & 64.67 & 49.62 & 58.77 & 74.28 & 54.55 & 61.89 & 80.69 \\
Setaria anceps & 33.39 & 40.63 & 45.83 & 50.82 & 58.07 & 66.40 & 54.24 & 59.94 & 82.33 & 56.93 & 68.57 & 88.20 \\
SEm \pm & 0.79 & 0.75 & 0.78 & 0.69 & 1.09 & 0.89 & 0.31 & 1.31 & 1.25 & 0.73 & 1.02 & 1.82 \\
CD at 5\% & 2.57 & 2.44 & 2.56 & 2.26 & 3.56 & 2.91 & 1.03 & 4.27 & 4.07 & 2.39 & 3.33 & 5.93 \\
\hline Mulching practices & & & & & & & & & & & & \\
\hline No mulching & 30.84 & 33.90 & 39.67 & 43.87 & 49.28 & 54.61 & 44.02 & 52.82 & 69.78 & 47.52 & 57.86 & 76.97 \\
Soil dust mulching & 31.40 & 36.79 & 42.07 & 46.52 & 51.78 & 58.22 & 46.80 & 54.97 & 72.82 & 49.69 & 60.33 & 78.74 \\
Live mulching & 31.93 & 37.99 & 44.58 & 48.31 & 54.57 & 60.55 & 52.33 & 59.65 & 78.98 & 52.93 & 65.73 & 83.22 \\
SEm \pm & 0.43 & 0.54 & 0.62 & 0.66 & 0.90 & 0.88 & 0.51 & 1.03 & 1.37 & 0.83 & 1.17 & 0.81 \\
CD at 5\% & $\mathrm{NS}$ & 1.57 & 1.82 & 1.93 & 2.64 & 2.58 & 1.48 & 3.02 & 4.00 & 2.43 & 3.41 & 2.37 \\
\hline
\end{tabular}

DAI- Days after initiation of season 
Himangshu Das et al. / J. Appl. \& Nat. Sci. 10(1): 266 - 271 (2018)

Table 2. Effect of mulching on crop growth rate $\left(\mathrm{g} \mathrm{m}^{-2}\right.$ day $\left.^{-1}\right)$ of forage crops during two seasons (pooled data of two years)

\begin{tabular}{|c|c|c|c|c|c|c|c|c|c|c|c|c|}
\hline \multirow{3}{*}{ Treatments } & \multicolumn{6}{|c|}{ Winter season } & \multicolumn{6}{|c|}{ Summer season } \\
\hline & $0-15$ & $16-30$ & $31-45$ & $46-60$ & $61-75$ & $76-90$ & $0-15$ & $16-30$ & $31-45$ & $46-60$ & $61-75$ & $76-90$ \\
\hline & DAI & DAI & DAI & DAI & DAI & DAI & DAI & DAI & DAI & DAI & DAI & DAI \\
\hline \multicolumn{13}{|l|}{ Forage crops } \\
\hline Brachiaria brizantha & 5.57 & 2.16 & 2.15 & 1.57 & 1.18 & 1.08 & 9.88 & 5.47 & 6.33 & 10.06 & 5.36 & 6.74 \\
\hline Panicum maximum & 7.36 & 2.58 & 2.38 & 1.77 & 1.52 & 1.26 & 9.28 & 4.77 & 5.93 & 9.64 & 5.16 & 6.37 \\
\hline Setaria anceps & 7.29 & 2.63 & 2.76 & 2.12 & 1.67 & 1.21 & 9.97 & 4.9 & 6.18 & 10.23 & 5.16 & 6.48 \\
\hline $\operatorname{SEm} \pm$ & 0.124 & 0.021 & 0.040 & 0.066 & 0.034 & 0.024 & 0.110 & 0.145 & 0.073 & 0.076 & 0.176 & 0.148 \\
\hline CD at $5 \%$ & 0.406 & 0.068 & 0.130 & 0.217 & 0.110 & 0.077 & 0.357 & 0.472 & 0.237 & 0.248 & NS & NS \\
\hline \multicolumn{13}{|l|}{ Mulching practices } \\
\hline No mulching & 6.48 & 2.37 & 2.14 & 1.59 & 1.37 & 1.03 & 8.52 & 4.58 & 5.38 & 9.28 & 4.84 & 6.08 \\
\hline Soil dust mulching & 6.86 & 2.41 & 2.36 & 1.83 & 1.49 & 1.16 & 9.57 & 5.09 & 6.09 & 9.88 & 5.18 & 6.57 \\
\hline Live mulching & 6.89 & 2.59 & 2.79 & 2.03 & 1.51 & 1.37 & 11.04 & 5.47 & 6.97 & 10.77 & 5.68 & 6.94 \\
\hline $\operatorname{SEm} \pm$ & 0.093 & 0.032 & 0.053 & 0.054 & 0.029 & 0.022 & 0.071 & 0.104 & 0.100 & 0.123 & 0.098 & 0.102 \\
\hline CD at $5 \%$ & 0.272 & 0.093 & 0.155 & 0.158 & 0.083 & 0.063 & 0.208 & 0.302 & 0.291 & 0.358 & 0.286 & 0.298 \\
\hline
\end{tabular}

DAI- Days after initiation of season

Table 3. Effect mulching practices on green forage and dry matter yield of forage crops in winter season

\begin{tabular}{lllllll}
\hline \multirow{2}{*}{ Treatments } & \multicolumn{2}{c}{ Green forage yield $\left(\mathbf{q ~ h a} \mathbf{~}^{-\mathbf{1}}\right)$} & \multicolumn{3}{c}{ Dry matter yield $\left(\mathbf{q} \mathbf{~ h a}^{-\mathbf{1}}\right)$} \\
\cline { 2 - 7 } & $\mathbf{2 0 1 2 - 1 3}$ & $\mathbf{2 0 1 3 - 1 4}$ & Pooled & $\mathbf{2 0 1 2 - 1 3}$ & $\mathbf{2 0 1 3 - 1 4}$ & Pooled \\
\hline Forage crops & & & & & & 22.33 \\
\hline Brachiaria brizantha & 80.67 & 77.00 & 78.83 & 22.69 & 21.98 & 25.22 \\
Panicum maximum & 87.11 & 80.00 & 83.56 & 26.49 & 23.95 & 26.27 \\
Setaria anceps & 91.22 & 91.06 & 91.14 & 27.69 & 24.86 & 0.16 \\
SEm \pm & 1.81 & 1.25 & 1.10 & 0.27 & 0.18 & 0.53 \\
CD at 5\% & 7.12 & 4.92 & 3.59 & 1.05 & 0.71 & 22.92 \\
\hline Mulching practices & & & & & & 21.55 \\
\hline No mulching & 78.00 & 73.11 & 75.56 & 24.30 & 23.76 & 26.28 \\
Soil dust mulching & 85.56 & 82.06 & 83.81 & 25.49 & 25.48 & 0.19 \\
Live mulching & 95.44 & 92.89 & 94.17 & 27.09 & 0.17 & 0.57 \\
SEm \pm & 1.04 & 1.74 & 1.01 & 0.35 & 0.53 & \\
CD at 5\% & 3.21 & 5.35 & 2.95 & 1.07 & & \\
\hline
\end{tabular}

Table 4. Effect mulching practices on green forage and dry matter yield of forage crops in summer season

\begin{tabular}{|c|c|c|c|c|c|c|}
\hline \multirow{2}{*}{ Treatments } & \multicolumn{3}{|c|}{ Green forage yield $\left(\mathrm{q} \mathrm{ha}^{-1}\right)$} & \multicolumn{3}{|c|}{ Dry matter yield $\left(\mathrm{q} \mathrm{ha}^{-1}\right)$} \\
\hline & 2013 & 2014 & Pooled & 2013 & 2014 & Pooled \\
\hline \multicolumn{7}{|l|}{ Forage crops } \\
\hline Brachiaria brizantha & 302.22 & 274.22 & 288.22 & 71.59 & 65.88 & 68.73 \\
\hline Panicum maximum & 258.33 & 237.56 & 247.94 & 68.63 & 63.13 & 65.88 \\
\hline Setaria anceps & 319.11 & 295.29 & 307.20 & 70.04 & 63.95 & 66.99 \\
\hline $\mathrm{SEm} \pm$ & 4.59 & 6.74 & 4.08 & 0.99 & 1.44 & 0.87 \\
\hline CD at $5 \%$ & 18.01 & 26.47 & 13.30 & NS & NS & NS \\
\hline \multicolumn{7}{|l|}{ Mulching practices } \\
\hline No mulching & 263.11 & 248.63 & 255.87 & 63.40 & 60.64 & 62.02 \\
\hline Soil dust mulching & 293.00 & 262.83 & 277.92 & 70.90 & 64.42 & 67.66 \\
\hline Live mulching & 323.56 & 295.61 & 309.58 & 75.96 & 67.90 & 71.93 \\
\hline $\mathrm{SEm} \pm$ & 4.25 & 4.90 & 3.24 & 0.93 & 1.25 & 0.78 \\
\hline CD at $5 \%$ & 13.11 & 15.09 & 9.47 & 2.87 & 3.86 & 2.28 \\
\hline
\end{tabular}

(Table 1). The maximum plant height (66.40 and 88.20 $\mathrm{cm}$ at final observation during winter and summer season, respectively) was recorded with Setaria anceps followed by Panicum maximum and Brachiaria brizantha. With the changes in forage types variation in plant height are well known because size of meristematic zone and rate of cell production are mainly contributed in increasing height and those are become differed within different types of plant, it is the consequent of variations in height of the different grasses (Guevara et al., 2002). Mulching had significant effect on plant height in all dates of observations except at 15
DAI during winter (Table 1). The highest plant height (60.55 and $83.22 \mathrm{~cm}$ at final observation during winter and summer season, respectively) was obtained where live mulch practiced at all the stages in both the seasons, whereas the lowest values $(54.61$ and $76.97 \mathrm{~cm}$ at final observation during winter and summer season, respectively) were obtained from no mulching treatment. Increase in plant height with mulch management also observed in other research work (Meena et al., 2014).

In general, a gradual increase in leaf area index (LAI) against time was recorded (Fig. 1 and 2), but in sum- 


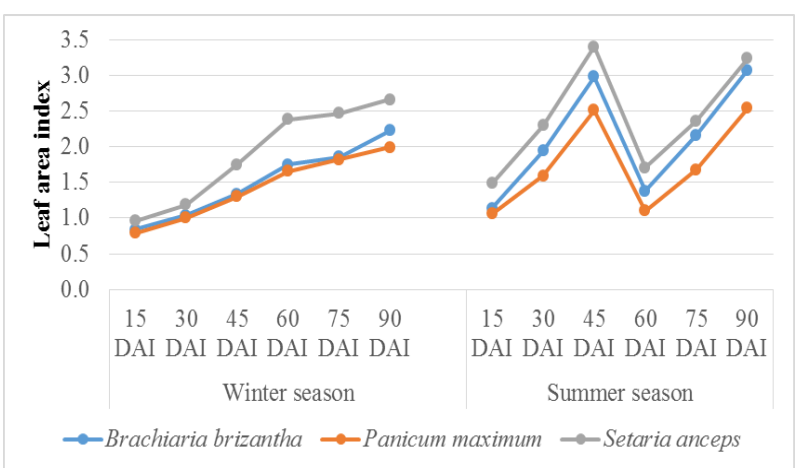

Fig. 1. Temporal changes in leaf area index (LAI) of different forage crops (data presented are averaged over mulching managements and two experimental years).

mer season there was a cut at 45 DAI that's why LAI at 60 DAI was reduced again (Fig. 1 and 2). Throughout the growing period, highest value of LAI (0.962.66 in winter and $1.49-3.40$ in summer) was recorded with forage grass Setaria anceps (Fig. 1). Different leaf size and its attachment with stem varied among forage types and hence showed variation in LAI (Anwar et al., 2012). In the present study, LAI was increased with live mulching (Fig. 2). Among the mulching managements, throughout the growing cycle live mulching recorded the highest LAI $(0.89-2.46$ during winter and $1.30-3.14$ during summer) followed by soil dust mulching and no mulching. Enormous increase in LAI under live mulching was due to increase rate of cell division and cell size enlargement under high availability of soil water (Xie et al., 2006; Kumar and Lal, 2012) to crop and better soil health condition due to legume mulching (Sharma et al., 2010).

Crop growth rate (CGR) was significantly influenced by different grasses during all observations, except at 61-75 and 76-90 DAI during summer season where no significant difference for CGR between forage crops were obtained (Table 2). On an average (0-90 DAI) pooled data showed higher CGR by Setaria anceps (2.95 and $7.15 \mathrm{~g} \mathrm{~m}^{-2}$ day $^{-1}$ in winter and summer season, respectively). In terms of CGR forage crop Panicum maximum positioned $2^{\text {nd }}$ in winter season and Brachiaria brizantha in summer season. Cutting was made about $15 \mathrm{~cm}$ from ground surface and when collected sample for dry matter it was made at ground surface resulting in higher CGR at 0-15 DAI in both seasons as well as at 46-60 DAI in summer season. The variation in CGR with the treatment was mainly due to the variation in dry matter production. Further, in winter season CGR reduced with advancement of time (Table 2) may due to be shortage of moisture because crop was cultivated without irrigation, but this trend was different owing to summer rainfall in the summer season. Mulching had significant effect on CGR (Table 2). The maximum CGR recorded with live mulching during both seasons. On the other hand,

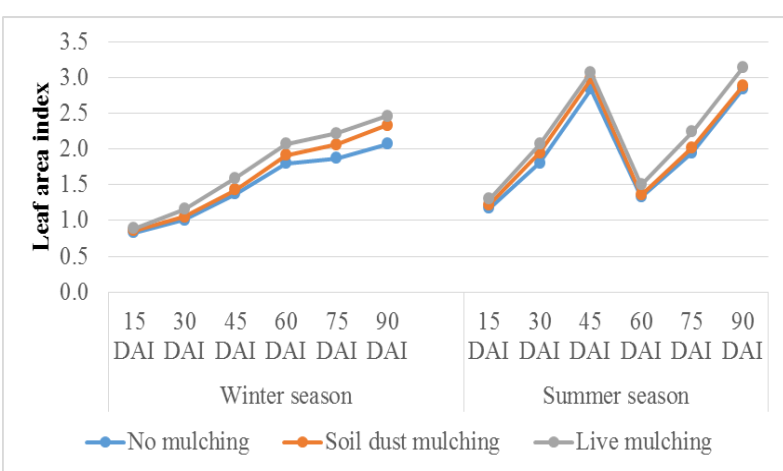

Fig. 2. Temporal changes in leaf area index (LAI) under different mulching crops (data presented are averaged over forage crops and two experimental years).

no mulched plot recorded minimum CGR values at all dates of observation. As per average of pooled data (090 DAI), higher CGR (2.86 and $7.81 \mathrm{~g} \mathrm{~m}^{-2}$ day $^{-1}$ in winter and summer season, respectively) was recorded with live mulching followed soil dust mulching. Adoption of mulching increases CGR might due to be reduced weed population and increases availability of soil moisture for crop use water (Xie et al., 2006; Kumar and Lal, 2012). Use of live mulching with legume improved the soil health (Sharma et al., 2010) resulted in better CGR value with live mulched treatment.

Yield: Yield was higher in $1^{\text {st }}$ year as compared to $2^{\text {nd }}$ year (Table 3 and 4). Among the seasons too much higher production was obtained in summer season. Seasonal variation in forage yield of perennial grasses was also reported by Ullah et al. (2006). Changes in forage type had a significant effect in changing the green forage yield during both years and seasons. Setaria anceps recorded significantly higher green forage yield during both seasons. (91.14 $\mathrm{q} \mathrm{ha}^{-1}$ in winter and $307.20 \mathrm{q} \mathrm{ha}^{-1}$ in summer). Growth parameters found superior with Setaria anceps may be the reasons for higher forage yield with this grass. In terms of green forage yield (GFY) forage crop Panicum maximum positioned $2^{\text {nd }}$ in winter season (Table 3 ) and $\mathrm{Bra}$ chiaria brizantha in summer season (Table 4). This was due to the perennial grasses have different growth habit and their response to environments is different (Langer, 1979). Dry matter yield (DMY) was also highest with Setaria anceps $\left(26.27 \mathrm{q} \mathrm{ha}^{-1}\right)$ followed by Panicum maximum (25.22 $\left.\mathrm{q} \mathrm{ha}^{-1}\right)$ and Brachiaria brizantha $\left(22.33 \mathrm{q} \mathrm{ha}^{-1}\right)$ in winter season. But, in summer season among the forages DMY was not significantly varied and recorded highest with Brachiaria brizantha (68.73 $\mathrm{q} \mathrm{ha}^{-1}$ ) followed by Setaria anceps (66.99 q ha ${ }^{1}$ ) and Panicum maximum (65.88 $\mathrm{q} \mathrm{ha}^{-1}$ ). Differences in fresh and dry biomass of grasses are due to differences in the growth habit and morphology (Ullah et al., 2006) and variations in assimilates allocation in different organs and its partitioning in above ground parts (Bandara et al., 1999) which differentiate grasses in biomass production from one another. Variation in 
sequence of fresh and dry biomass of grasses is due to different in water content in biomass (Anwar et al., 2012). Significantly highest green forage yield obtained with live mulching (94.17 and $309.58 \mathrm{q} \mathrm{ha}^{-1}$ in winter and summer season, respectively) followed by soil dust mulching and no mulching recorded the lowest GFY (Table 3 and 4). GFY increased by 12.36 to $24.63 \%$ in winter season and 11.39 and $20.99 \%$ in summer season with live mulching treatment as compared to soil dust mulching and no mulching. Dry matter yield was also increased by 6.74 to $14.66 \%$ in winter season and 6.31 to $15.98 \%$ in summer season with live mulching treatment as compared to soil dust mulching and no mulching (Table 3 and 4). Nodulation under live mulch improve soil nutrient status (Sharma et al., 2010) and on an average add 20.90 to 21.54 and 27.89 to $28.11 \mathrm{~kg} \mathrm{~N} \mathrm{ha}^{-1}$ during both seasons through biomass of mulching plant. Cutting the intercropped legume plants and using it as mulch after 45 days helped in suppressing weed growth, and led checking evaporation losses (Narain and Singh, 1997) resulted in better growth attributing characters and ultimately maximum green forage and dry matter yield obtained under live mulching. In zero mulched plots there might be more evaporation loss of moisture. Hence, the resulting water stress in the crop lead to lower values in growth attributing characters as well as green forage and dry matter yield. Soil dust mulching also conserve moisture but yield level was less than that of live mulching due to better soil health was observed with live mulching.

\section{Conclusion}

From present study it can be concluded that overall performance of forage crop Setaria anceps was preeminent as compared to others. Live mulching significantly affected the growth and yield of the perennial forage crops and has an important role on increasing green forage and dry matter yield.

\section{REFERENCES}

Anwar, M., Akmal, M., Shah, A., Asim, M. and Gohar, R. (2012). Growth and yield comparison of perennial grasses as rainfed fodder production. Pakistan Journal of Botany, 44 (2): 547-552.

Bandara, G.D., Whitehead, D., Mead, D.J. and Moot, D.J. (1999). Effects of pruning and understorey vegetation on crown development, biomass increment and aboveground carbon partitioning in Pinus radiata D. Don trees growing at a dryland agroforestry site. Forest Ecology and Management, 172: 241-254.

Bajoriene, K., Jodaugiene, D., Pupaliene., R and Sinkeviciene, A. (2013). Effect of organic mulches on the content of organic carbon in the soil. Estonian Journal of Ecology, 62(2): 100-106.

DADF, (2014-15). Annual Report, 2014-15. Department of Animal Husbandry, Dairying \& Fisheries, Ministry of Agriculture, Government of India, New Delhi.

DADF, (2016-17). Annual Report, 2016-17. Department of
Animal Husbandry, Dairying \& Fisheries, Ministry of Agriculture, Government of India, New Delhi.

Gomez, K.A. and Gomez, A.A. (1984). Statistical Procedures for Agricultural Research (2 ${ }^{\text {nd }}$ Eds.) A wiley Interscience publication, New York. pp 680.

Guevara, J.C., Gonnet, J.M. and Esteve, O.R. (2002). Biomass estimation for native perennial grasses in the plain of Mendoza, Argentina. Journal of Arid Environments, 50(4): 613-619.

Jackson, M. (1967). Soil Chemical Analysis. Prentice Hall of India Pvt. Ltd; New Delhi.

Jackson, M.L. (1973). Soil Chemical Analysis, Prentice Hall of India Private Ltd., New, Delhi, pp 498.

Kaur, G and Goyal, M. (2017). Effect of growth stages and fertility levels on growth, yield and quality of fodder oats (Avena sativa L.). Journal of Applied and Natural Science, 9(3): 1287-1296.

Kemp, C.D. (1960). Methods of estimation of the leaf area of grasses from linear Measurement. Annual Boval New Series, 2: 96.

Kumar, R., Sood, S., Sharma, S., Kasana, R.C., Pathania, V.L., Singh, B. and Singh., R.D. (2014). Effect of plant spacing and organic mulch on growth, yield and quality of natural sweetener plant Stevia and soil fertility in western Himalayas. International Journal of Plant Production, 8(3): 311-333.

Kumar, S., Agrawal, R.K., Dixit, A.K., Rai, A.K. and Rai, S.K. (2012). Forage Crops and Their Management. Indian Grassland and Fodder Research Institute, Jhansi284003, Uttar Pradesh, India. pp 60.

Kumar, S.D. and Lal, B.R. (2012). Effect of Mulching on Crop Production under Rainfed Condition: A Review. International Journal of Research in Chemistry and Environment, 2(2): 8-10.

Kumar, V. (2014). Effect of different organic mulching materials on soil properties of na ' 7 ' aonla (emblica officinalis gaertn) under rainfed condition of shiwalik foothills of Himalayas India. The Bioscan, 9(1): 561-564.

Langer, R.H.M. (1979). How grasses grow, $2^{\text {nd }}$ Ed. Edward Arnold (Publishers) Ltd. London.

Meena, S.L., Meena, S.S. and Nagar, R.P. (2014). Influence of soil moisture conservation techniques on the performance of fodder crops under semi-arid environments. In: Abstracts, National Symposium on climate Resilient Forage production and its utilization. November, 13-14, 2014. Bidhan Chandra KrishiViswavidyalaya, Kalyani, West Bengal, India. pp 23-24.

Narain, P. and Singh, R.K. (1997). Erosion control and productivity through sunnhemp mulching and green manuring. Annual Report. Central Soil and water Conservation Research and Training Institute, Dehradun, pp 40-41.

Patil N.N., Rao V.K., Dimri D.C. and Sharma S.K. (2016). Effect of mulching on soil properties, growth and yield of strawberry cv. Chandler under mid hill conditions of Uttarakhand. Progressive Horticulture, 48(1): 42-47.

Patil, S.S., Kelkar, T.S. and Bhalerao, S.A. (2013). Mulching: A Soil and Water Conservation Practice. Research Journal of Agriculture and Forestry Sciences, 1(3): 2629.

Schollenberger, C.J. and Simon, R.H. (1945). Determination of exchange capacity and exchangeable bases in soilsammonium acetate method. Soil Science, 59: 13-24. 
Sharma, A.R., Singh, R., Dhyani, S.K. and Dube, R.K. (2010). Moisture conservation and nitrogen recycling through legume mulching in rainfed maize (Zea mays)wheat (Triticuma estivum) cropping system. Nutrient Cycling in Agroecosystems, 87: 187-197.

Subbaiah, B.V. and Asija, G.L. (1956). A rapid procedure for the estimation of available nitrogen in soil. Current Science, 25: 259-260.

Teame, G., Tsegay, A. and Abrha, B. (2017). Effect of organic mulching on soil moisture, yield, and yield contributing components of sesame (Sesamum indicum L.). International Journal of Agronomy, 2017: 1-6.

Ullah, M.A., Razzaq, A. and Saleem, R. (2006). Performance of various forage grasses under spring and mon- soon season at pothowar plateau. International Journal of Agriculture \& Biology, 8 (3): 398-401.

Walkey, A. and Black, I.A. (1934). An examination of the Degtjareff method for determining soil organic matter and a proposed modification of the cromic acid titration method. Soil Science, 34: 29-38.

Watson, D.J. (1947). Comparative Physiological studies on the growth of field crops II. The effect of varying nutrient supply on the net assimilation rate. Annals of Bota$n y, 11: 375-407$.

Xie, Z., Wang, Y., Jiang, W. and Wei, X. (2006). Evaporation and evapotranspiration in a watermelon field mulched with gravel of different sizes in northwest China. Agricultural Water Management, 81: 173-184. 